\title{
RANCANG BANGUN ALAT UKUR PM10 RENDAH BIAYA MENGGUNAKAN SENSOR DEBU GP2Y1010AU0F
}

\author{
Rady Purbakawaca ${ }^{1 *}$, Kania Nur Sawitri ${ }^{1}$, Muhammad Rido ${ }^{1}$, Aris Irvan ${ }^{1}$, Oky Lidya \\ Kumala ${ }^{1}$, Jajang Nurjaman ${ }^{1}$, Helni Kurniawati Zebua ${ }^{1}$, Eka Fitriandini ${ }^{1}$, Lia Amalia ${ }^{2}$ \\ ${ }^{1}$ Program Studi Fisika, Fakultas Sains dan Teknologi, Universitas Jambi, Mendalo Darat, Jambi 36361 \\ ${ }^{2}$ Program Studi Teknik Sipil, Sekolah Tinggi Teknologi Cirebon, Kota Cirebon, Jawa Barat 45132 \\ E-mail: radyp09@gmail.com
}

\begin{abstract}
Abstrak
Bahan partikulat dengan ukuran lebih kecil dari $10 \mu \mathrm{m}$ (PM10) telah dikaji dalam berbagai penelitian sebagai salah satu polutan utama di udara. Monitoring PM10 dibuthkan untuk mengevaluasi kualitas udara pada area spesifik. Propinsi Jambi hanya memiliki tiga stasiun pengukuran kualitas udara, dan satu diantaranya tidak aktif. Informasi polusi PM10 yang didapatkan dari kedua stasiun lainnya hanya tersedia di situs Kementrian Lingkungan Hidup dan data diakumulasi sekali tiap hari. Batasan-batasan tersebut merupakan latar belakang dari penelitian ini untuk merancang alat pengukur PM10 yang portabel, mudah digunakan, rendah biaya, dan simultan. Sensor debu GP2Y1010AUOF digunakan sebagai penghitung PM10 dengan metode optik dan frekuensi 280ms. Data keluaran dari sensor diproses oleh mikrokontroler menggunakan formula kalibrasi yang disediakan oleh pabrik sensor tersebut. Informasi konsentrasi PM1O ditampilkan di layar LCD dan disimpan dalam mikroSD. Uji performa dilaksanakan di Mendalo, Universitas Jambi pada 7 Maret (16.00-18.00), 8 Maret (12.00-14.00), dan 11 Maret 2017 (08.00-10.00). Hasil masing-masing pengukuran menunjukkan bahwa konsentrasi PM10 adalah $145.6 \mu \mathrm{g} / \mathrm{m}^{3}, 149.5 \mu \mathrm{g} / \mathrm{m}^{3}$, dan $157.7 \mu \mathrm{g} / \mathrm{m}^{3}$. Merujuk pada PP No. 41 (1990), hasil yang didapatkan pada tanggal 11 Maret 2017 melebihi standar kualitas partikulat $\left(150 \mu \mathrm{g} / \mathrm{m}^{3}\right)$. Alat ini berpotensi untuk dikembangkan lebih lanjut sebagai instrumen monitoring kualitas udara.
\end{abstract}

Kata Kunci: Monitoring polusi udara, PM10, Jambi, GP2Y1010AUOF

\begin{abstract}
[Title: DESIGN OF LOW COST PM10 MEASUREMENT DEVICE USING DUST SENSOR GP2Y1010AUOF] Particulate matter (PM10) has been studied on many research as one of the major air pollutant. PM10 monitoring is needed to evaluate the air quality on the specific area. Jambi province only has three air quality measurement stations, and one of them is not active. The information of PM10 pollution from those two stations is only available on the website of Ministry of Live Environment accumulated once per day. Those limitations are the background of this research to design a portable, easy to use, low cost, and real time PM10 measurement device. Dust sensor GP2Y1010AUOF were used as PM1O counter with frequency 280 ms by optical method. Output data from the sensor were processed by microcontroller using calibration formula from the manufacturer. The information of PM1O concentration were displayed on LCD monitor and saved in the micro SD. The performance test were conducted at Mendalo, University of Jambi on March, 7th (4.00-6.00 pm), 8th (0.00-2.00 pm), 11th (8.00-10.00 am) 2017. The result showed that PM10 concentrations are $145.6 \mu \mathrm{g} / \mathrm{m}^{3}, 149.5 \mu \mathrm{g} / \mathrm{m}^{3}$, and $157.7 \mu \mathrm{g} / \mathrm{m}^{3}$, respectively. According to PP No. 41 (1990), the result which obtained on March 11 th 2017 exceed quality standard of particulate $\left(150 \mu \mathrm{g} / \mathrm{m}^{3}\right)$. This device is potentially developed as air quality monitoring instrument
\end{abstract}

Keywords: Air pollution monitoring, PM10, Jambi, GP2Y1010AUOF. 


\section{PENDAHULUAN}

Pemantauan indeks kualitas udara (IKU) perkotaan secara harian merupakan salah satu tindakan evaluasi kesehatan lingkungan yang dilakukan oleh Kementrian Lingkungan Hidup Indonesia. Hasil evaluasi tersebut akan digunakan untuk mengambil kebijakan-kebijakan berkaitan dengan pemeliharan dan pengembangan kesehatan lingkungan. Ada lima parameter konsentrasi digunakan dalam pemantauan kualitas udara yaitu Ozon (O3), bahan partikulat dengan diameter kurang dari $10 \mu \mathrm{m}$ (PM10), Karbon Monoksida (CO), Sulfur Dioksida (SO2), dan Nitrogen Oksida (NO2) (Kep-45 MENLH 1997).

Salah satu parameter yang dievaluasi untuk Kota Jambi adalah konsentrasi PM10. Data PM10 didapat dari tiga stasiun yang terletak di Bandara Sultan Thaha Syaifuddin, Lapangan Kantor Walikota dan Jl. H. Zainir Haviz. Akan tetapi, stasiun ketiga yang berada di Jl. H. Zainir Haviz dalam keadaan non aktif (IKU MENLH 2017).

Data keluaran dari setiap stasiun bersifat regional atau mewakili daerah di sekitarnya saja, sehingga tidak dapat menggambarkan kualitas udara untuk daerah yang letaknya jauh dari stasiun tersebut sedangkan penambahan jumlah stasiun akan membutuhkan biaya operasional yang besar dan persiapan yang lama. Di sisi lain, informasi konsentrasi PM10 perlu diberikan kepada masyarakat secara luas sebagai tindakan awareness terhadap kesehatan lingkungan hidup. Tindakan tersebut diperlukan karena PM10 memiliki dampak yang berbahaya pada kesehatan tubuh jika melebihi baku mutu yang telah ditetapkan dalam PP No. 41 Tahun 1999 yaitu $150 \mu \mathrm{g} / \mathrm{m}^{3}$ (data hasil pengukuran selama 24 jam). Ukuran PM10 yang kecil menyebabkan PM10 lebih mudah masuk ke saluran pernapasan atas. Beberapa penyakit yang dapat disebabkan oleh PM10 diantaranya adalah gangguan pernapasan atas, serangan jantung, perubahan komposisi darah, bahkan kematian pada kasus-kasus tertentu (Fauzi et al. 2013).

Berdasarkan masalah di atas maka penelitian ini mengkaji pembuatan alat ukur konsentrasi PM10 yang murah, mudah digunakan, mudah dibawa dan dapat memberikan hasil secara langsung menggunakan sensor GP2Y1010AU0F. Pemanfaatan alat tersebut dengan baik dan sistematis diharapkan dapat membantu masyarakat untuk lebih peduli terhadap kesehatan lingkungan. Alat ukur yang dirancang dalam penelitian ini tidak hanya dapat mengukur konsensentrasi PM10 untuk kondisi di luar ruangan tetapi juga dapat mengukur di dalam ruangan.

\section{METODE}

Penelitian ini dilakukan di dua lokasi, yaitu lokasi Universitas Jambi, Mendalo Darat pada koordinat 1'36'27.6'S 10331'11.9'”E dengan lalu lintas padat karena berada di area jalan lintas timur yang menghubungkan Provinsi Jambi dan Sumatra Barat, dan Lapangan Perumahan Pinang Merah pada koordinat 1'36'3.012” S 103³0'3.07”. Penelitian ini dibagi ke dalam beberapa tahapan, yaitu analisis sistem, perancangan dan fabrikasi alat PM10, pengujian, pengukuran konsentrasi PM10, serta analisis hasil pengukuran.

\subsection{Analisis Sistem}

Pada tahap ini dilakukan analisis yang mencakup segala kebutuhan dalam membangun sistem alat ukur PM10 dengan mengidentifikasi masalah yang mecangkup model rancangan, sensor debu dan rangkaian perangkat keras, perangkat lunak, dan sistem akuisisi data.

\subsection{Perancangan dan Fabrikasi Alat PM10}

Tahap perancangan diawali dengan pengembangan sensor debu GP2Y1010AUOF dan perangkat keras untuk mengukur konsentasi PM10. Perangkat keras dibangun atas unit catu daya, sensor temperatur (T) dan kelembaban relatif (RH) udara DHT22, pencatat waktu (Real Time Clock) RTCDS3231, layar Liquid Crystal Display (LCD) untuk menampilkan data hasil pengukuran. Adapun skematik rangkaian sensor dan perangkat keras ditunjukkan seperti pada Gambar 1.

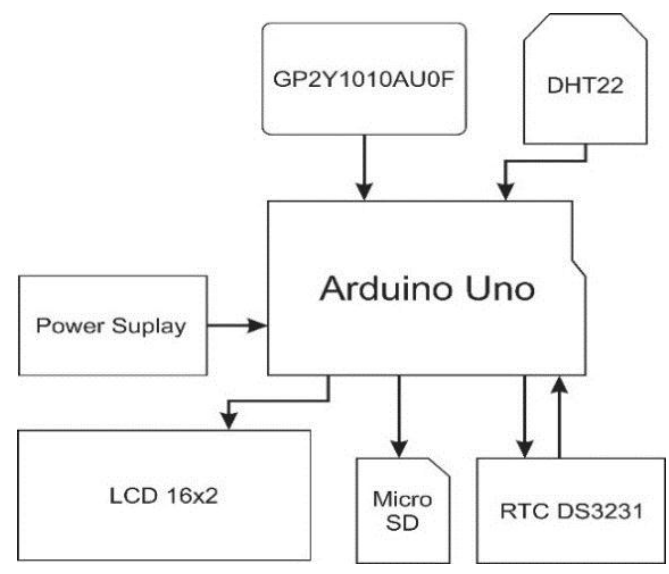

Gambar 1. Skema rangkaian alat PM10

Alat ukur PM10 juga didesain dengan kemampuan untuk menyimpan data pada media micro SD dengan kapasitas 4 GB. Data ditulis (write) pada file jenis csv untuk memudahkan analisis lanjutan. Adapun format penyimpanan data ditunjukkan pada Tabel 1. 
Tabel 1. Format penyimpanan data

\begin{tabular}{|c|c|c|c|c|c|c|}
\hline Date & Time & $\begin{array}{c}\text { ADC } \\
\text { Value }\end{array}$ & $\begin{array}{c}\text { Voltage } \\
(\text { Volt })\end{array}$ & $\begin{array}{c}\text { PM10 } \\
(\mathrm{mg} / \mathrm{m3})\end{array}$ & $\begin{array}{c}\text { Temp } \\
{ }^{*} \mathrm{C}\end{array}$ & $\begin{array}{c}\mathrm{RH} \\
(\%)\end{array}$ \\
\hline $\mathrm{d} / \mathrm{m} / \mathrm{y}$ & h:m:s & $\mathrm{xxx}$ & $\mathrm{xx} . \mathrm{x}$ & $\mathrm{xx} . \mathrm{x}$ & $\mathrm{xx} . \mathrm{x}$ & $\mathrm{xx} . \mathrm{x}$ \\
\hline
\end{tabular}
dilakukan pembuatan dan penyesuaian program untuk melakukan serangkaian tahapan dan pengujian sistem. Pengujian sistem dilakukan untuk memastikan masing-masing blok rangkaian perangkat keras bekerja dengan benar dan mengikuti alur kerja sistem. Adapun alur kerja alat ukur PM10 ditunjukkan seperti pada Gambar 2.

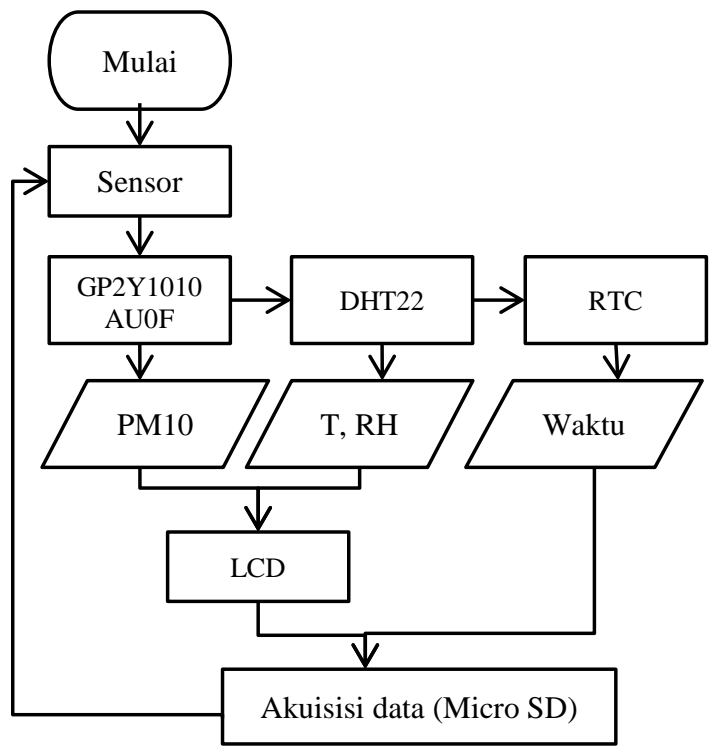

Gambar 2. Diagram alur kerja alat ukur PM10

\subsection{Pengujian dan Percobaan Lapang}

Setelah seluruh bagian alat telah difabrikasi maka langkah selanjutnya yaitu melakukan uji performa secara keseluruhan. Pengujian dimaksudkan untuk mengetahui kinerja dari alat ukur PM10 sebelum melakukan pengambilan data. Hal ini dapat mengurangi dan menanggulangi kesalahan yang terjadi pada saat alat ini dioperasikan di lapangan uji coba.

Pengujian dilakukan dengan cara mengoperasikan alat selama beberapa waktu pada saat kondisi ada dan tidak ada debu atau asap. Data yang tersimpan di dalam micro SD kemudian diamati dan dianalisa untuk mengetahui adanya kesalahan yang terjadi.

\subsection{Pengukuran PM10}

Pengukuran PM10 dilakukan dibeberapa lokasi pada waktu yang berbeda. Pengukuran pertama dilakukan di tempat yang diduga terdapat tingkat pencemaran udara yang tinggi yaitu di depan Universitas Jambi. Pengukuran kedua dilakukan disalah satu ruang kuliah RK-8 Fakultas Sains dan Teknologi. Pengukuran yang terakhir dilakukan di lapangan Perumahan Pinang Merah. Masing-masing pengukuran dilakukan selama 24 jam secara kontinyu.

\subsubsection{Analisis Data}

Data yang diambil merupakan data pembacaan sensor debu GP2Y1010AU0F yang telah dikonversi menjadi nilai konsentrasi PM10 berdasarkan grafik hubungan intensitas debu dan tegangan. Data yang diperoleh dapat menggambarkan kategori kualitas udara pada lokasi pengukuran.

\section{HASIL DAN PEMBAHASAN}

\section{a. Analisa Kinerja GP2Y1010AU0F}

Uji kinerja sensor debu dilakukan dengan dua tahap. Pengujian tahap pertama dilakukan dengan cara mengukur konsentrasi debu udara ambien dan konsentasi asap rokok. Gambar 3 menunjukkan hasil pengukuran konsentrasi asap rokok lebih tinggi dibandingkan konsentasi debu udara ambien. Nilai rata-rata pengukuran konsentrasi asap rokok dan debu udara ambien masing-masing sebesar $135.90 \mu \mathrm{g} / \mathrm{m}^{3}$ dan $92.06 \mu \mathrm{g} / \mathrm{m}^{3}$. Nilai deviasi asap rokok sebesar 22.42 lebih kecil dibanding udara ambien. Ini menunjukkan bahwa saat pengukuran berlangsung kondisi asap rokok memiliki kondisi yang lebih seragam dibandingkan debu udara ambien. Hasil pengukuran ini menunjukkan bahwa sensor mampu mampu mendeteksi perbedaan densitas konsentrasi debu.

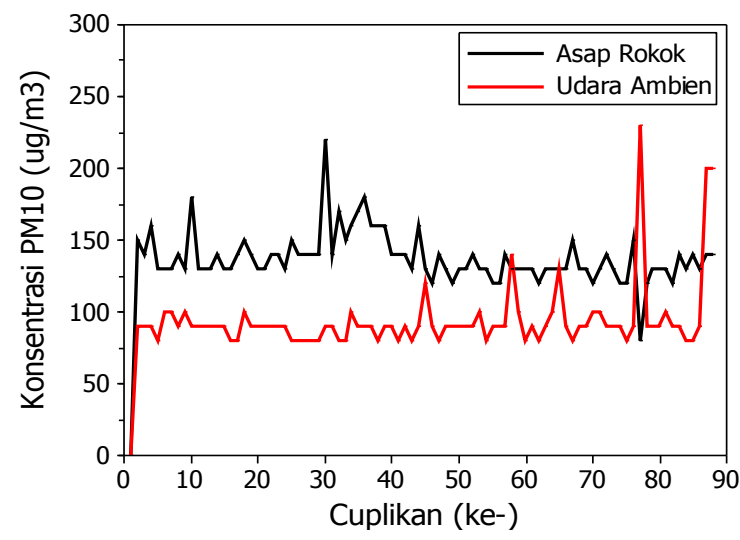

Gambar 3. Perbedaan hasil pengukuran konsentrasi debu udara ambien dengan konsentrasi rokok

Pengujian tahap kedua dilakukan dengan mengukur konsentasi PM10 di depan gerbang masuk Universitas Jambi pada tanggal 7, 8, dan 11 Maret 2016. Pada tanggal 7 maret 2017, 
pengukuran berlangsung pada pukul 16.00 - 18.00 WIB dengan nilai rata-rata konsentrasi PM10 sebesar $150.04 \mathrm{ug} / \mathrm{m}^{3}$ dan deviasi sebesar 17.76. Pada tanggal 8 maret 2017, pengukuran berlangsung pada pukul 12.00 - 14.00 WIB dengan nilai rata-rata konsentrasi PM10 sebesar 147.54 $\mathrm{ug} / \mathrm{m}^{3}$ dan deviasi sebesar 21.28. Pada tanggal 11 maret 2017, pengukuran berlangsung pada pukul 7.30 - 9.30 WIB dengan nilai rata-rata konsentrasi PM10 sebesar $157.73 \mathrm{ug} / \mathrm{m}^{3}$ dan deviasi sebesar 14.62. Nilai konsentrasi terbesar terjadi pada tanggal 7 Maret pagi hari dan 11 maret sore yang disebabkan pada waktu pengukuran tersebut terjadi peningkatan jumlah kendaraan yang signifikan akibat jam masuk dan pulang kerja atau kuliah.

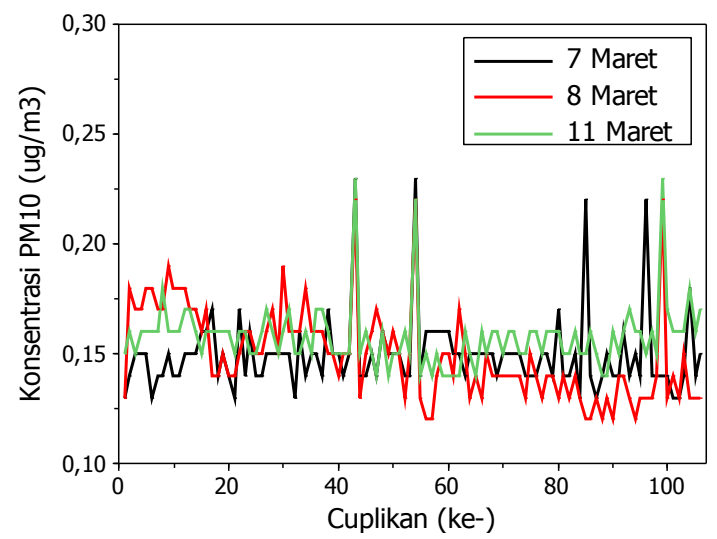

Gambar 4. Perbedaan hasil pengukuran konsentrasi PM10 pada tanggal 7, 8 dan 11 Maret 2017

\section{b. Analisa Kinerja Perangkat Keras dan Lunak}

Analisa kinerja perangkat keras dan lunak dapat dilakukan secara bersamaan berdasarkan pesan yang muncul pada data yang tersimpan pada micro SD. Kegagalan pada sistem maupun pada blok rangkaian akan menyebabkan pesan "Error !" pada file CSV. Error yang muncul akan menyebabkan sistem berhenti bekerja. Pesan yang muncul akibat kegagalan kinerja RTC ditunjukkan pada Gambar 5(a), kegagalan pada RTC akan menyebabkan sistem berhenti tanpa adanya proses pengukuran temperatur, kelembaban udara, dan konsentrasi PM10 oleh sistem. Kegagalan pada sensor DHT22 masih memungkinkan waktu pengukuran tersimpan pada micro SD, ini bertujuan agar kegagalan dapat diketahui kejadiannya, tapi tidak memungkinkan konsentasi PM10 dilakukan pengukuran oleh sistem seperti pada Gambar 5(b). Pada Gambar 5(c) menunjukkan bahwa sistem bekerja dengan benar dan tidak terdapat adanya kesalahan maupun pesan error pada file CSV.

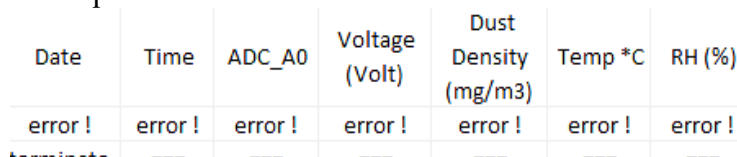

terminate === ==- ==- ==- ==" ==

\begin{tabular}{|c|c|c|c|c|c|c|}
\hline \multicolumn{7}{|c|}{ (a) } \\
\hline Date & Time & ADC_A0 & $\begin{array}{l}\text { Voltage } \\
\text { (Volt) }\end{array}$ & $\begin{array}{c}\text { Dust } \\
\text { Density } \\
(\mathrm{mg} / \mathrm{m} 3)\end{array}$ & Temp ${ }^{*} \mathrm{C}$ & $\mathrm{RH}(\%)$ \\
\hline $04 / 08 / 2017$ & $16: 00: 32$ & error! & error! & error! & error! & error \\
\hline terminate & $===$ & $===$ & $\begin{array}{l}=== \\
\text { (b) }\end{array}$ & $===$ & $===$ & $===$ \\
\hline Date & Time & $A D C \_A 0$ & $\begin{array}{l}\text { Voltage } \\
\text { (Volt) }\end{array}$ & $\begin{array}{c}\text { Dust } \\
\text { Density } \\
(\mathrm{mg} / \mathrm{m} 3)\end{array}$ & Temp ${ }^{*} \mathrm{C}$ & $\mathrm{RH}(\%)$ \\
\hline $04 / 08 / 2017$ & $15: 44: 58$ & 303 & 0.98 & 70 & 30.3 & 62 \\
\hline $04 / 08 / 2017$ & $15: 45: 58$ & 341 & 1.1 & 90 & 30.5 & 61.4 \\
\hline $04 / 08 / 2017$ & $15: 46: 58$ & 329 & 1.06 & 80 & 30.9 & 60.3 \\
\hline 04/08/2017 & $15: 47: 58$ & 340 & 1.1 & 90 & 31 & 60.1 \\
\hline
\end{tabular}

(c)

Gambar 5. Pesan error yang muncul pada file CSV akibat kesalahan (a) RTC, (b) sensor DHT22, dan (c) sistem bekerja dengan benar

\section{c. Pengukuran konsentrasi PM10}

Hasil pengukuran pertama yang dilakukan di Lapangan Pinang Merah pada tanggal 28 Maret 2017 pukul 08:02:18 - 29 Maret 2017 pukul 08:02:18 ditunjukkan pada Gambar 6. Nilai konsentrasi PM10 berada pada rentang 50-160 $\mu g / \mathrm{m}^{3}$.

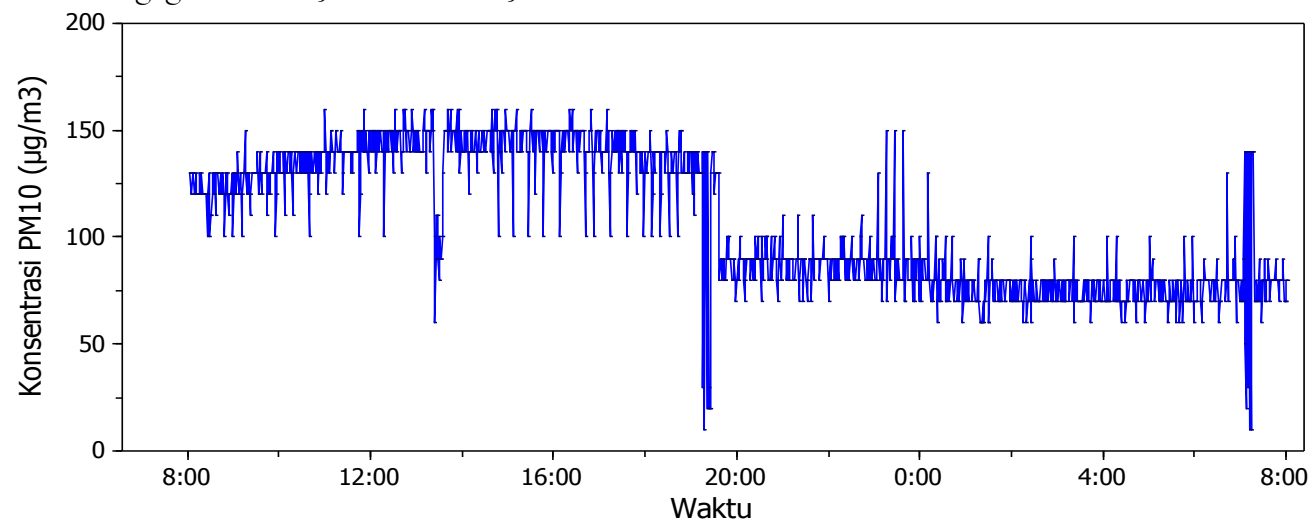

Gambar 6. Hasil Pengukuran konsentrasi PM10 di Lapangan Pinang Merah pada tanggal 28 Maret 2017 pukul 08:02:18 29 Maret 2017 pukul 08:02:18 
Rata-rata konsentrasi PM10 pada pukul pagi hari 08:02:18-18:32:18 adalah $125 \mu \mathrm{g} / \mathrm{m}^{3}$ dengan puncak pada pukul 12:57:00, kemudian turun menjadi $80 \mu \mathrm{g} / \mathrm{m}^{3}$ pada pukul 18:32:18 00:32:18, lalu menurun kembali menjadi 70 $\mu \mathrm{g} / \mathrm{m}^{3}$ pada pukul 00:32:18 - 08:02:18. Kenaikan nilai konsentrasi PM10 pada pagi sampai siang hari disebabkan oleh meningkatnya aktivitas masyarakat pada jam tersebut, sedangkan penurunan nilai konsentrasi PM10 pada sore hari dan malam hari dikarenakan masyarakat tidak lagi beraktivitas di luar ruangan pada jam tersebut.

Hasil pengukuran kedua yang dilakukan di dalam sekretariat fisika pada tanggal 01 April 2017 pukul 14:08:06-02 April 2017 pukul 14:08:14 ditunjukkan pada Gambar 7. Nilai konsentrasi PM10 berada pada rentang 10-50 $\mu \mathrm{g} / \mathrm{m}^{3}$. Rata-rata konsentrasi PM10 pada pukul sore hari 14:08:0619:35:02 adalah $35 \mu \mathrm{g} / \mathrm{m}^{3}$, kemudian turun menjadi $25 \mu \mathrm{g} / \mathrm{m}^{3}$ pada malam hari pukul
19:35:02-01:42:51, lalu meningkat kembali menjadi $35 \mu \mathrm{g} / \mathrm{m}^{3}$ pada subuh hari pukul 01:42:51 - 07:50:40, dan menurun kembali menjadi 25 $\mu \mathrm{g} / \mathrm{m}^{3}$ pada pagi hari pukul 07:50:40-14:08:06. Ruangan sekretariat fisika memiliki kapasitas sekitar 20 orang dan dipergunakan oleh mahasiswa saat melakukan kegiatan tertentu. Ruangan ini lebih banyak dipergunakaan saat sore hari untuk perkuliahan dan juga untuk ruang belajar sehingga nilai konsentrasi PM10 pada jam ini lebih tinggi daripada jam lainnya. Berdasarkan Gambar 8 dapat dilihat bahwa konsentrasi PM10 di dalam ruangan nilainya lebih rendah daripada konsentrasi PM10 di luar ruangan (Gambar 6), hal ini dikarenakan sedikitnya sumber pembangkit partikulat di dalam ruangan dibandingkan di luar ruangan. Sedangkan pada pagi hari ruangan tersebut jarang dipergunakan oleh mahasiswa sehingga nilai konsentrasi PM10 pada jam ini lebih remdah daripada konsentrasi PM10 di sore hari.

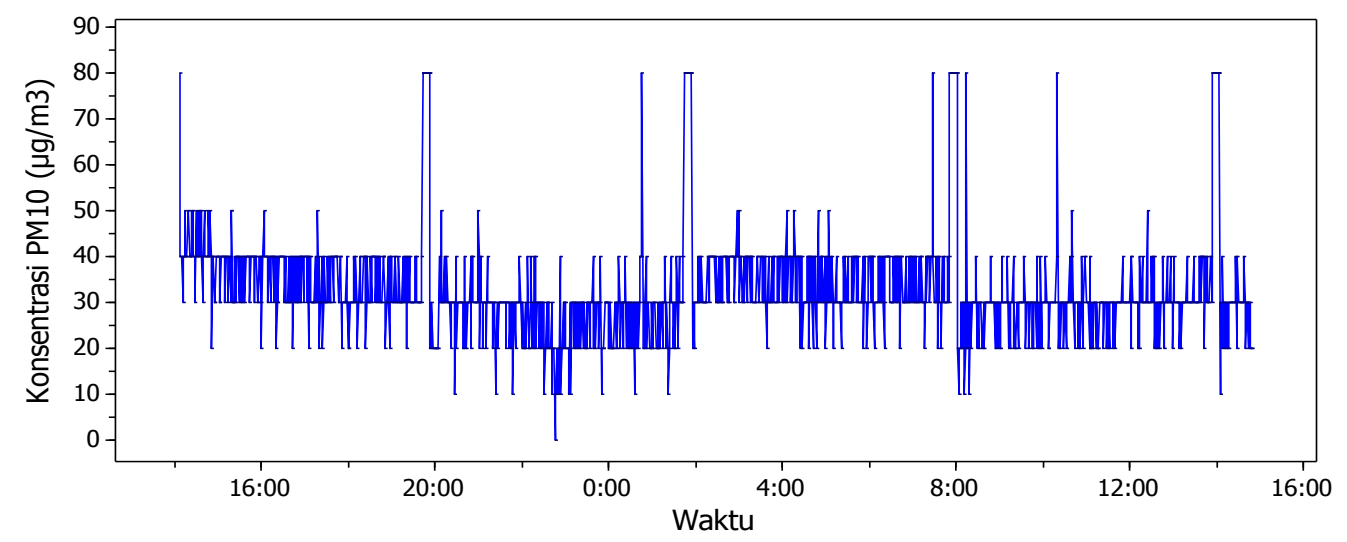

Gambar 7. Hasil Pengukuran konsentrasi PM10 di dalam ruang sekretariat fisika pada tanggal 01 April 2017 14:08:06-02 April 2017 14:08:1

Hasil pengukuran ketiga yang dilakukan di depan Universitas Jambi pada tanggal 08 April 2017 pukul 15:44:00 - 09 April 2017 pukul 15:44:56 ditunjukkan pada Gambar 8. Nilai konsentrasi PM10 berada pada rentang 60-160 $\mu \mathrm{g} / \mathrm{m}^{3}$. Rata-rata konsentrasi PM10 pada pukul sore hari 15:44:00-20:47:36 adalah $100 \mu \mathrm{g} / \mathrm{m}^{3}$, kemudian turun menjadi $80 \mu \mathrm{g} / \mathrm{m}^{3}$ pada malam hari pukul 20:47:36-06:56:01, lalu meningkat drastis menjadi $120 \mu \mathrm{g} / \mathrm{m}^{3}$ pada pagi hari pukul 06:56:01 - 11:59:38. Penurunan nilai konsentrasi PM10 pada malam hari disebabkan oleh menurunnya jumlah kendaraan yang melintasi Universitas Jambi, sedangkan kenaikan nilai konsentrasi PM10 pada pagi hari disebabkan oleh tingginya volume kendaraan yang dipergunakan oleh akademisi Universitas Jambi dan masyarakat.
Berdasarkan pengukuran yang telah dilakukan, alat ukur PM10 telah bekerja dengan baik karena dapat mendeteksi perubahan konsentrasi PM10 di udara sekitar baik dalam ruangan maupun di luar ruangan. Pengukuran dilakukan selama 24 jam dan memberikan nilai rata konsentrasi PM10 sebesar $110 \mu \mathrm{g} / \mathrm{m}^{3}, 32 \mu \mathrm{g} / \mathrm{m}^{3}$, dan $99 \mu \mathrm{g} / \mathrm{m}^{3}$ untuk setiap pengukuran. Ketiga nilai tersebut masih berada dibawah baku mutu yang ditetapkan berbahaya oleh pemerintah melalui PP No. 41 Tahun 1999 yaitu $150 \mu \mathrm{g} / \mathrm{m}^{3}$. Indeks ISPU tiap pengukuran dapat dihitung menggunakan Persamaan 1, sehingga didapatkan nilai 80, 32 dan 75. Indeks ISPU 32 di dalam sekretariat fisika masuk ke dalam kategori baik sehingga tidak ada efek PM10 terhadap kesehatan. Sedangkan indeks ISPU di lapangan Perumahan Pinang Merah dan di depan Universitas Jambi, masing-masing 80 dan 75, masuk ke dalam 
kategori sedang sehingga PM10 memberikan efek penurunan jarak pandang tetapi tidak menimbulkan penyakit.

Menurut beberapa referensi penelitian diketahui bahwa konsentrasi polutan di udara juga dipengaruhi oleh parameter meteorologi seperti temperatur, kelembaban udara, arah angin, kecepatan angin dan lainnya. Parameter-parameter tersebut membuat PM10 terdifusi, dilusi, dan terakumulasi (Wang dan Ogawa, 2015). Pada penelitian ini parameter yang dikaji adalah temperatur dan kelembaban udara.

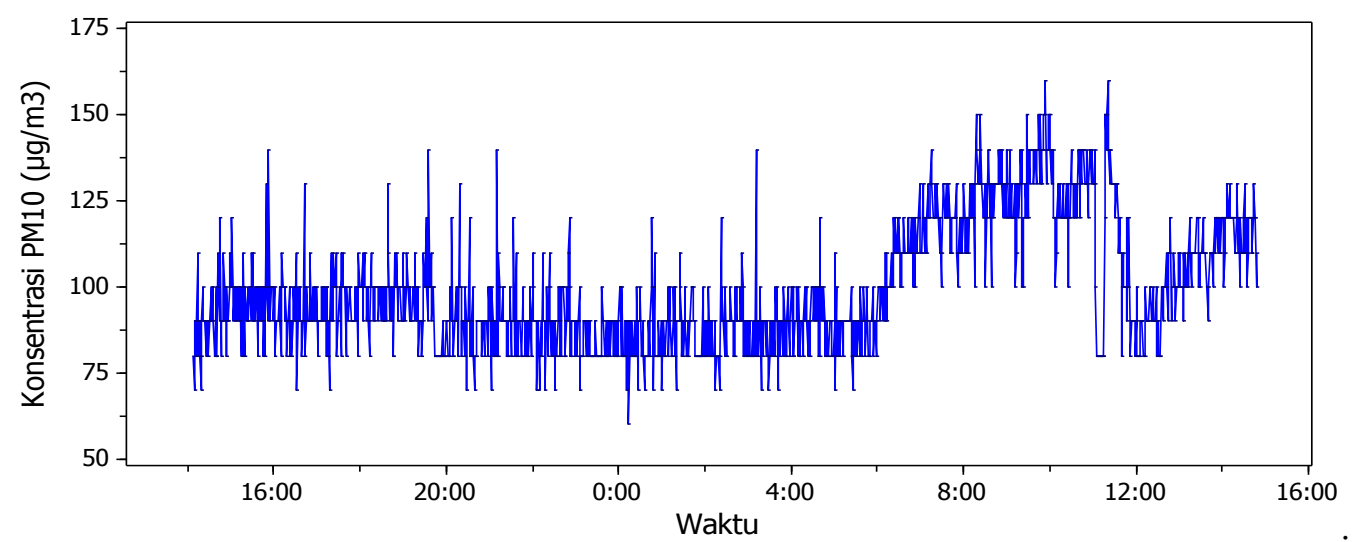

Gambar 8. Hasil Pengukuran konsentrasi PM10 di depan gerbang masuk Universitas Jambi pada tanggal 08 April 2017 15:44:00-09 April 2017 15:44:56

Pada Gambar 9(a) dan 9b) terlihat bahwa konsentrasi PM10 meningkat seiring dengan meningkatnya nilai temperatur. Temperatur pengukuran di lapangan Perumahan pinang merah berada pada rentang $30-39{ }^{\circ} \mathrm{C}$, sedangkan di dalam sekretariat fisika berada pada rentang 30.5-33.5 ${ }^{\circ} \mathrm{C}$. Pada Gambar 9(c) terlihat bahwa konsentrasi PM10 meningkat seiring dengan meningkatnya nilai temperatur. Temperatur Pengukuran di depan Universitas Jambi berada pada rentang yang lebih lebar yaitu $25-41{ }^{\circ} \mathrm{C}$. Berdasarkan hasil di atas dapat disimpulkan bahwa konsentrasi PM10 memiliki hubungan linear positif dengan temperatur. Hal ini dapat dikaji baik secara fisika maupun kimia. Kenaikan temperatur memberikan energi kinetik yang lebih untuk partikel-partikel udara sehingga bergerak lebih cepat akibatnya lebih banyak PM10 yang berterbangan di udara. Secara kimiawi, kenaikan temperatur akan mengubah formasi partikel dan juga akan menimbulkan reaksi fotokimia antar senyawa kimia polutan.

Koefisien determinasi untuk masingmasing pengukuran dapat dilihat pada Tabel 2 . Pengukuran dengan koefisien determinasi paling tinggi (0.9156) adalah pengukuran di depan Universitas Jambi. Pengukuran dengan koefisien determinasi paling rendah (0.011) adalah pengukuran di dalam sekretariat fisika.

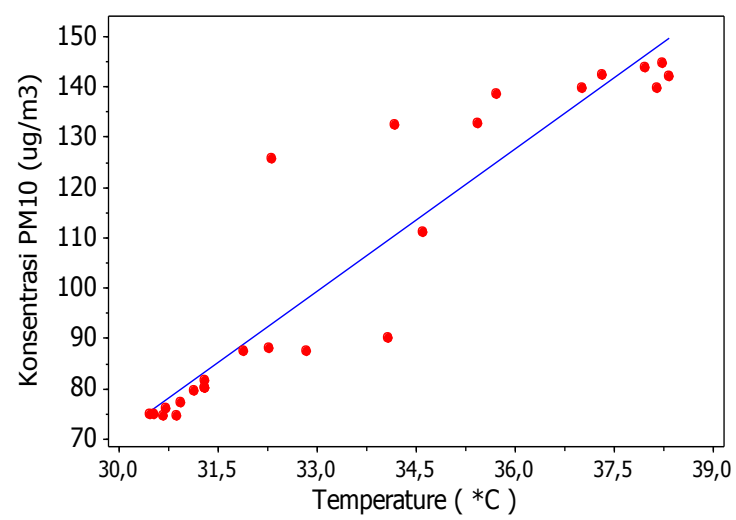

(a)

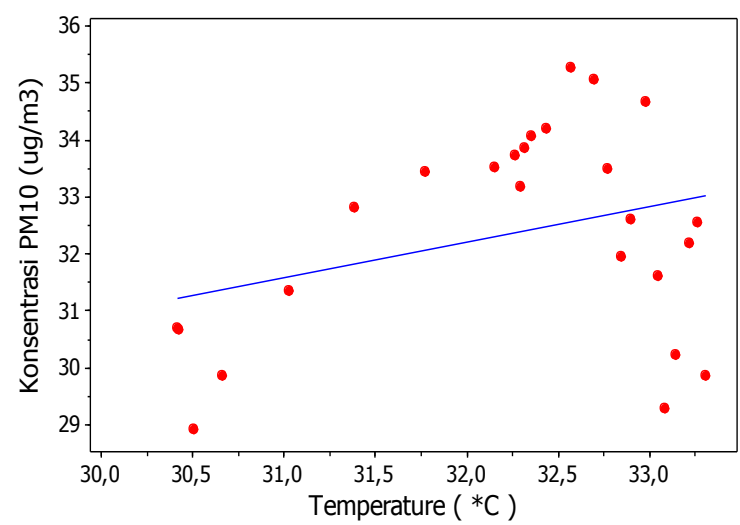

(b) 


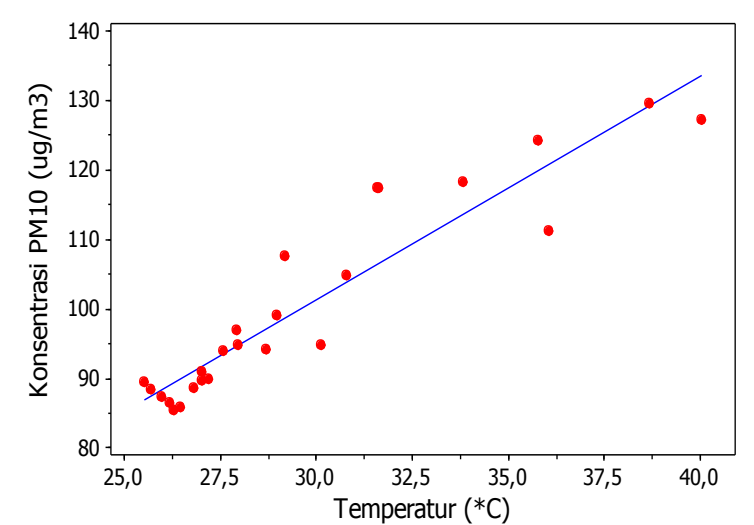

(c)

Gambar 9. Hubungan konsentrasi PM10 dengan temperatur $\left({ }^{\circ} \mathrm{C}\right)$ pada pengukuran (a) di lapangan Perumahan Pinang Merah (b) di dalam sekretariat fisika (c) di depan Universitas Jambi, menggunakan moving average dengan step 100

Tabel 2. Korelasi linear antara temperatur dengan konsentrasi PM10 pada setiap pengukuran

\begin{tabular}{crrr}
\hline Pengukuran ke: & $\mathbf{1}$ & $\mathbf{2}$ & $\mathbf{3}$ \\
\hline $\boldsymbol{R}^{\mathbf{2}}$ & 0.8557 & 0.011 & 0.9156 \\
\hline
\end{tabular}

Pada Gambar 10(a) terlihat bahwa konsentrasi PM10 menurun seiring dengan meningkatnya nilai kelembaban udara. Kelembaban pengukuran di lapangan Perumahan pinang merah berada pada rentang 31-53\%. sedangkan pada Gambar 10(b) terlihat bahwa konsentrasi PM10 menurun seiring dengan menurunnya nilai kelembaban udara. Kelembaban pengukuran di dalam sekretariat fisika berada pada rentang 46-53 $\%$.

Pada Gambar 10(c) terlihat bahwa konsentrasi PM10 meningkat seiring dengan menurunnya nilai kelembaban udara. Kelembaban pengukuran di depan Universitas Jambi berada pada nilai yang lebih tinggi yaitu 31-85\% karena banyak terdapat pohon besar pada area tersebut. Berdasarkan hasil di atas dapat disimpulkan bahwa konsentrasi PM10 memiliki hubungan linear negatif dengan kelembaban udara walaupun untuk pengukuran di dalam sekretariat fisika menunjukkan korelasi positif dengan koefisien determinasi yang sangat kecil yaitu 0.0169. Saat kelembaban udara tinggi maka udara banyak mengandung air sehingga massa polutan menjadi lebih berat dan tidak dapat bertahan lama di udara. Polutan kemudian jatuh ke tanah sehingga jumlah partikulat berkurang dan menurunkan nilai konsentrasi PM10.
Koefisien determinasi untuk masing-masing pengukuran dapat dilihat pada Tabel 3. Pengukuran dengan koefisien determinasi paling tinggi (-0.836) adalah pengukuran di depan Universitas Jambi. Pengukuran dengan koefisien determinasi paling rendah (0.0169) adalah pengukuran di dalam sekretariat fisika.

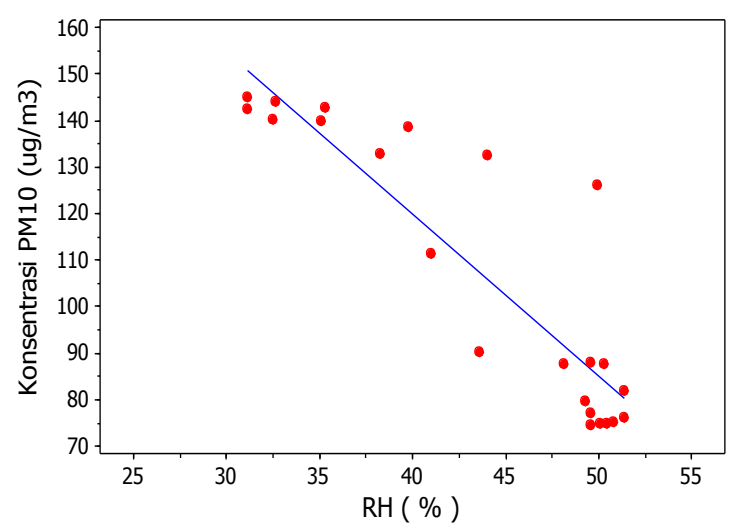

(a)

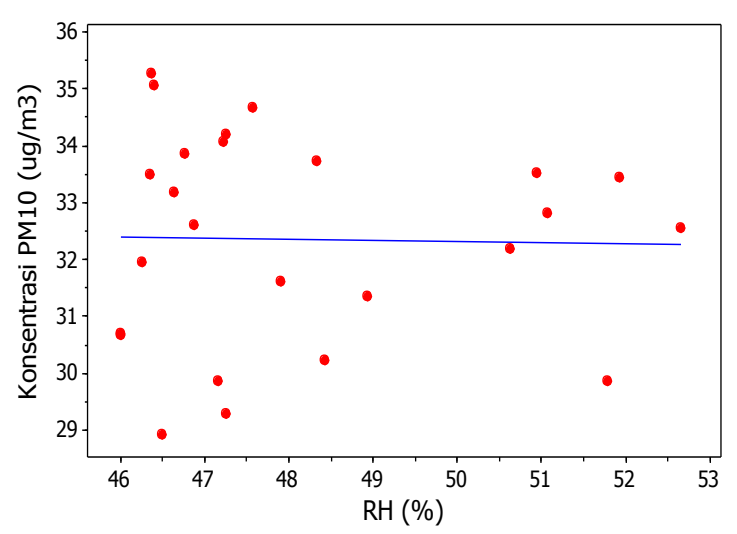

(b)

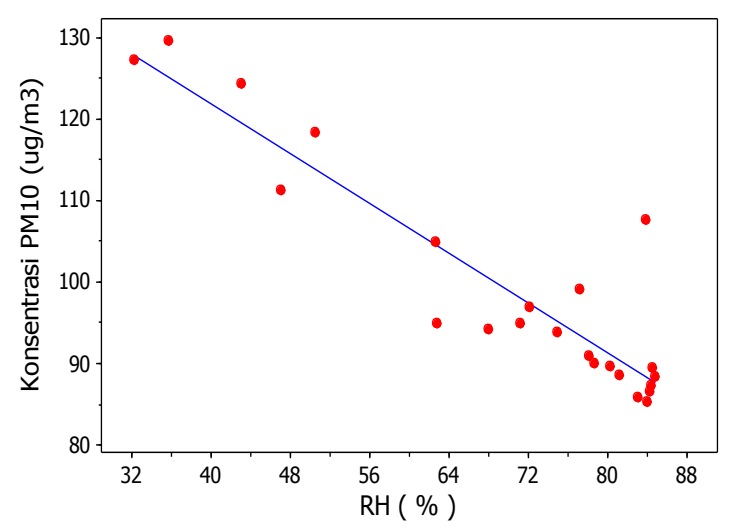

(c)

Gambar 1 Hubungan konsentrasi PM10 dengan kelembaban udara (\%) pada pengukuran (a) di lapangan Perumahan Pinang Merah (b) di dalam sekretariat fisika (c) di depan Universitas Jambi, menggunakan moving average dengan step 100 
Tabel 3. Korelasi linear antara kelembaban dengan konsentrasi PM10 pada setiap pengukuran

\begin{tabular}{crrr}
\hline Pengukuran ke: & $\mathbf{1}$ & $\mathbf{2}$ & $\mathbf{3}$ \\
\hline $\boldsymbol{R}^{\mathbf{2}}$ & -0.7914 & 0.0169 & -0.836 \\
\hline
\end{tabular}

\section{SIMPULAN DAN SARAN}

Alat ukur konsentrasi PM10 telah berhasil dibuat dan diuji coba selama 24 jam di tiga lokasi yang berbeda. Alat ukur ini dapat membedakan konsentrasi PM10 di udara serta menyimpan datanya di dalam micro SD. Berdasarkan hasil pengukuran dapat disimpulkan bahwa temperatur berkorelasi positif dengan konsentrasi PM10 sedangkan kelembaban udara berkorelasi negatif dengan konsentrasi PM10

\section{DAFTAR PUSTAKA}

Fauzi A, et al. 2013. Status Lingkungan Hidup Indonesia 2012: Pilar Lingkungan Hidup Indonesia. Jakarta: Kementrian Lingkungan Hidup Indonesia

[Kep-45 MENLH]. 1997. Keputusan Menteri Negara Lingkungan Hidup No. 45 Tahun 1997 Tentang Indeks Standar Pencemar Udara. [diunduh 2017 Maret 29]. Tersedia pada: $\quad$ http://storage.jakstik.ac.id/ProdukHukum/LingkunganHidup /IND-PUU-7-1997-kepmen\%20451997.pdf

[IKU MENLH]. 2017. Indeks Kualitas Udara Perkotaan - Kementrian Lingkungan Hidup. Tersedia pada: http://iku.menlhk.go.id

[PP-41]. 1999. Peraturan Pemerintah no. 41 tahun 1999 tentang: pengendalian pencemaran udara. [diunduh 2017 Maret 29]. Tersedia pada:

http://jdih.den.go.id/download/19/peratu ran-pemerintah-no-41-tahun-1999

Wang, J dan Ogawa, S. 2015. Effects of Meteorological Conditions on PM2.5 Concentrations in Nagasaki, Japan. Int. J. Environ. Res. Public Health. 12. 90 